\title{
Genetics and prevention of blindness
}

\author{
Genética e prevençãoda cegueira
}

\author{
Priscila Hae Hyun Rim ${ }^{1}$ \\ Luis Alberto Magna ${ }^{2}$ \\ AntonioSérgio Ramalho ${ }^{3}$
}

\begin{tabular}{l} 
ABSTRACT \\
\hline Purpose: To verify the perception of Brazilian ophthalmologists regarding \\
the role played by Genetics in their routine medical activity and their \\
conduct when dealing with patients, with hereditary diseases who need \\
genetic counseling. Methods: A cross-sectional survey was conducted by \\
means of invitations to participate in an interview on this subject. The \\
questionnaires were sent to 200 ophthalmologists who work in the area of \\
Campinas, SP, Brazil. Results: Among the 73 professionals who answered \\
the questionnaire (36\%), there was a high rate of positive answers (49-88\%) \\
concerning their knowledge of genetics and a low rate (10-33\%) of use of \\
this knowledge in their clinical practice. The frequency of genetic ophthal- \\
mopathies in clinical practice was relevant in the opinion of $68 \%$ of the \\
interviewees; $92 \%$ indicated a relevant relationship between genetically \\
determined ocular disorders and the prevention of blindness through \\
detection, early treatment and genetic counseling. More extensive genetic \\
knowledge was considered indispensable to $84 \%$ of the professionals, but \\
16\% answered that it was irrelevant. Conclusions: Although these ophthal- \\
mologists have basic notions of genetics (88,0\%) and are aware of its \\
importance in the prevention of blindness, a great majority of Brazilian \\
ophthalmologists have not acquired adequate knowledge of genetics and, \\
in practice, rarely use its therapeutic and preventive potential.
\end{tabular}

Keywords: Genetic counseling; Knowledge, attitudes and practice; Eye diseases, hereditary; Blindness/prevention \& control

\section{INTRODUCTION}

In countries with high-level economies, a proportionally high occurrence of genetically determined eye diseases is due to a low prevalence of preventable and curable eye disorders ${ }^{(1)}$. As developing countries progress regarding the control of infectious-parasitic diseases, genetic alterations now occupy an outstandingly high statistical rank as one of the causes of morbidity and mortality. Therefore, in Brazil, genetically transmitted diseases are now routinely diagnosed in several medical specialties such as Ophthalmology. Since 1980, François noticed that more than $50 \%$ of all eye diseases are due to a genetic factor ${ }^{(2)}$. Nowadays, many researchers believe that as much as $90 \%$ medical diseases either have a major genetic component or involve genetic factors that significantly influence the disease ${ }^{(3)}$. Genetic factor is obvious in most single-gene ocular disease and many of the numerically weighty ocular diseases, such as glaucoma, age-related macular degeneration, age-related cataract, strabismus and high myopia, exhibit complex etiologies including genetic factor ${ }^{(1)}$. Thus, it is very common to find patients with hereditary diseases at ophthalmological practice, most of them presenting problems that are not clinically serious. However, 
some patients present more serious alterations that could result in blindness and require correct genetic counseling besides adequate treatment.

Blindness and visual impairment have far-reaching implications for society. Studies performed in blind schools, from 13 countries in Latin America, Asia and Africa, revealed that genetic disease was a major cause of childhood blindness affecting 11-39\% of the pupils, while in the Nordic countries, genetic etiology accounts for $31-40 \%{ }^{(4)}$. In countries with high consanguinity rates, hereditary disease was responsible for $59-80 \%$, due to autosomal recessive conditions, counting retinal dystrophies such as retinitis pigmentosa, congenital glaucoma and Leber's amaurosis ${ }^{(5)}$.

According to the Bulletin of the World Health Organization: "It is estimated that, in almost half of the children who are blind today, the underlying cause could have been prevented, or the eye condition treated to preserve vision or restore sight"(6). One of the strategies based on activities to prevent blindness should consider the possibility of inclusion of the genetically determined eye conditions in national programs of community genetics. This new branch of Genetics, created officially by WHO in 1998, is defined as bringing genetic services to the community as a whole, in its applied form ${ }^{(7)}$. Community programs include population screening, genetic counseling and information and education for professionals and the public $^{(8-9)}$. Studies on this issue revealed that culture aspects, including religion and misbelieves related to the causes and implications of blindness and ocular health, affect the patient's behavior, influencing the treatment of the diseases ${ }^{(10-11)}$. Taking into account the nature of the issue and its consequences, genetic counseling includes effective programs of communitybased action for health promotion and prevention of diseases, delivered, since long ago, by intervention of public health ${ }^{(12)}$.

The possibility of a condition having a hereditary character adds on other components to the clinical treatment and medical responsibility. In fact, individuals who present the risk of giving birth to children with these diseases have the right to be informed, through genetic counseling, of the hereditary aspects and other clinical implications of the problem. Genetic counseling, therefore, is not an optional procedure or the exclusive responsibility of the geneticist, but an important component of the medical procedures to be applied and its omission is considered a serious failure. On the other hand, genetic counseling presents important psychological, social and legal implications that consequently brings a high degree of responsibility to institutions and clinics that offer this service. Thus, it is indispensable that it should be offered by skilled professionals having a vast experience and be controlled by rigorous ethical and scientific standards ${ }^{(13)}$.

According to Ramalho (1986), the goals of genetic counseling are far greater than the discussion of eventual risks of occurrence or recurrence of the disorder within a family ${ }^{(14)}$. Genetic counseling is the process of communicating genetic information as a non-directive care process aimed at helping individuals or families to focus on risk assessment, decision- making, and potential medical and psychological implications including the treatment available and its efficacy, its prognosis, the importance of early diagnosis and the possibility of prenatal diagnosis ${ }^{(15-16)}$. A lot of hereditary ocular disorders such as congenital cataract and congenital glaucoma, awareness of the risk of disease manifestation in a child to be born and consequently early treatment may be adequate enough to prevent blindness ${ }^{(17)}$.

The Human Genome Project will bring a revolutionary change to the XXI century and therefore, Brazilian ophthalmologists and other health professionals should incorporate genetic perspective in their routine clinical practice ${ }^{(16,18)}$. However, they are not expected to turn into genetic counselors, but they should be able to recognize or suspect of the genetic etiology of their patients' diseases, particularly those that lead to severe visual impairment (low vision or blindness) and refer these patients and their families to a skilled service that provides adequate genetic counseling with the highest ethical, technical and scientific standards ${ }^{(13,19)}$.

The new technologies and the Human Genome Project databases have brought about a new understanding of the fundamental causes of diseases and highlighted therapy, with the hope that new treatments might be found to prevent blindness. We are beginning to consider targeting specific therapies for these conditions, like gene therapy and pharmacogenetics ${ }^{(16,20)}$. It will not be long before a pathological gene is replaced by a normal gene or the pathogenic gene is inactivated ${ }^{(21-22)}$.

A review of the literature found little information about how doctors in various specialties manage the genetic problems of the patients they see as part of their routine practice, nor whether they have the necessary skills, or access to genetic services ${ }^{(23)}$. Therefore, there is an increasing need for health professional understanding of the use of genetic methodo$\operatorname{logy}$ in routine practice ${ }^{(20,24)}$.

The purpose of this study was to verify the perception of Brazilian ophthalmologists regarding the role of Genetics in routine medical practice as well as their educational practices in relation to individuals and their families at risk of genetic disorders and in need of genetic counseling. This testimony is essential for diagnosing the present situation, so that realistic strategies can be planned in relation to the incorporation of genetic methodology in the clinical routine, as well as in programs of community health.

\section{METHODS}

A cross-sectional survey was conducted by means of invitations sent by mailed questionnaire to 200 ophthalmologists practicing in the area of Campinas, SP, Brazil (universities and/or private clinics). All subjects participated voluntarily. The questionnaire used in the interview consisted of "closed answers" (multiple choice) that permitted a statistical analysis with calculations of percentage and a comparison of proportions. 
The following variables were selected: sex, age, number of years after graduation, postgraduation courses, medical residence, present links with universities, duration of the genetic course during graduation. The reported statistical inferences are based on chi-square analyses $\left(\chi^{2}\right)$, which were applied to compare proportions, adopting whenever needed $\chi^{2}$ corrected or Fisher's exact test with the two-sided $\mathrm{p}$ value $=0.05$.

\section{RESULTS}

The response rate was $36 \%$ of the total of the sent questionnaires and the ophthalmologists returned it by mail $(n=73)$.

The characteristics of respondents are presented in table 1 .

Replies to the questionnaire were grouped in the form of tables to facilitate analysis. Table 2 presents the knowledge acquired by the ophthalmologists in genetics, including their concepts of genes and chromosomes, Mendelian inheritance, teratogenesis and prenatal diagnosis. In table 3, their clinical management in relation to patients with hereditary ocular diseases is presented and, in table 4, their opinions, including the importance of these disorders in clinical practice and the relevance of genetic counseling in the prevention of blindness is described. Other variables, such as postgraduation courses, medical residence and professional practice in Medical Schools influenced some of the answers (Tables 2, 3 and 4).

\section{DISCUSSION}

Genetics now occupies an outstanding position in medicine and therefore, it is indispensable that it should be part of the medical graduation curriculum, residency courses and updating courses, not only to enhance and update information but primarily to teach about its use in clinical practice ${ }^{(25)}$.
Analysis of the results obtained in this study showed that, in general, the ophthalmologists had basic notions of genetics and were aware of its importance in the prevention of blindness (Tables 2 and 4, respectively). Nonetheless, these theo-

\begin{tabular}{|c|c|c|}
\hline Characteristics & $\mathbf{N}$ & $\%$ \\
\hline \multicolumn{3}{|l|}{ Sex } \\
\hline Male & 54 & 74 \\
\hline Female & 19 & 26 \\
\hline \multicolumn{3}{|l|}{ Age } \\
\hline Up to 40 years & 30 & 41 \\
\hline$>40$ years & 43 & 59 \\
\hline \multicolumn{3}{|l|}{ Medical experience } \\
\hline 1 to 10 years & 15 & 21 \\
\hline 11 to 20 years & 27 & 37 \\
\hline 21 to 30 years & 25 & 34 \\
\hline More than 30 years & 6 & 8 \\
\hline \multicolumn{3}{|l|}{ Medical residency } \\
\hline 2 years & 35 & 48 \\
\hline 3 years or more & 35 & 48 \\
\hline no residency & 3 & 4 \\
\hline \multicolumn{3}{|l|}{ Postgraduation } \\
\hline Yes & 22 & 30 \\
\hline No & 51 & 70 \\
\hline \multicolumn{3}{|l|}{ Clinical activities } \\
\hline Private clinic & 68 & 93 \\
\hline Work only in hospitals & 5 & 7 \\
\hline Affiliation to medical schools & 36 & 49 \\
\hline No links with medical schools & 37 & 51 \\
\hline \multicolumn{3}{|l|}{ Course in genetics at graduation } \\
\hline Up to 30 hours & 41 & 56 \\
\hline More than 30 hours & 25 & 34 \\
\hline No course & 7 & 10 \\
\hline
\end{tabular}

\begin{tabular}{|c|c|c|c|}
\hline Knowledge & Yes & No & Variables with significantly higher proportion of affirmative answers \\
\hline Concepts of genes and chromosomes & $64-88$ & 9-12 & Accomplishment of postgraduate courses (Fisher's exact test: $p=0.047$ ) \\
\hline Mendelian inheritance & $62-85$ & $11-15$ & None \\
\hline Multifactorial inheritance & $46-63$ & $27-37$ & None \\
\hline Teratogenesis & $45-62$ & $28-38$ & Medical residency - duration 3 years or more $\left(\chi^{2}=4.88 ; p=0.0271\right)$ \\
\hline Prenatal diagnostics & $36-49$ & $37-51$ & $\begin{array}{l}\text { Professional practice in medical schools }\left(\chi^{2}=3.95 ; p=0.046\right) \\
\text { Course in genetics during graduation - more than } 30 \text { hours }\left(\chi^{2}=5.81 ; p=0.015\right)\end{array}$ \\
\hline
\end{tabular}

\begin{tabular}{|c|c|c|c|}
\hline Practices & Yes & No & Variables with significantly higher proportion of affirmative answers \\
\hline Pedigree is included in the clinical chart & $7-10$ & $66-90$ & Accomplished postgraduate course $\left(\chi^{2}=4.29 ; p=0.038\right)$ \\
\hline $\begin{array}{l}\text { Patient's familial consanguinity routinely } \\
\text { investigated }\end{array}$ & 24-33 & $49-67$ & Medical residency - duration 3 years or more $\left(\chi^{2}=4.24 ; p=0.039\right)$ \\
\hline $\begin{array}{l}\text { Confident regarding counseling and } \\
\text { information on genetic diseases }\end{array}$ & $12-16$ & $61-84$ & None \\
\hline Refers patients to genetic clinics & $58-79$ & $15-21$ & Accomplished postgraduate course (Fisher's exact test: $p=0.034$ ) \\
\hline These referrals are frequent & 22-38 & $36-62$ & None \\
\hline
\end{tabular}


Table 4. Ophthalmologist's opinion

\begin{tabular}{|c|c|c|c|}
\hline Opinions & Very important & Irrelevant & $\begin{array}{l}\text { Variables with significantly higher } \\
\text { proportion of affirmative answers }\end{array}$ \\
\hline $\begin{array}{l}\text { Importance of genetic } \\
\text { ophthalmopathies in clinical practice }\end{array}$ & $50-68$ & $23-32$ & Professional link with the university $\left(\chi^{2}=4.79 ; p=0.028\right)$ \\
\hline $\begin{array}{l}\text { Importance of genetic counseling } \\
\text { in the prevention of blindness }\end{array}$ & $67-92$ & $6-8$ & None \\
\hline To improve knowledge on genetics & $61-84$ & $12-16$ & None \\
\hline
\end{tabular}

retical notions remained restricted to their graduation course or medical residency as genetic methodology was rarely used in their clinical practice and, since the knowledge was incomplete, it's therapeutic and preventive potential was almost totally unexplored. It is also important to stress that inadequate perception and use of the preventive and therapeutic potential of genetic counseling may be even deeper than one could observe in this sample for two main reasons:

1) $64 \%$ of the ophthalmologists invited to participate in the study did not answer the questionnaire, demonstrating either lack of interest or knowledge;

2) These ophthalmologists work in the area of Campinas, a city with two medical schools that offer courses in genetics (one of them has medical residency as well as postgraduation in genetics) and frequently conducts updating courses in this area.

Taking into account the limitations of the genetic course in most of the interviewees (Table 1), it is plausible to suppose that the observed results among the ophthalmologists can be generalized to other medical specialties. Such fact demands changes in the genetic course in undergraduate programs. The significant difference observed in relation to postgraduate professionals regarding concepts of genes and chromosomes, inclusion of pedigrees and patients' referral to genetic services, suggests that these professionals were more aware of genetic factors.

The frequency of genetic ophthalmopathies in clinical practice was considered rare by $32 \%$ of the interviewees (Table 4), which is in contrast with the fact, as mentioned before, that $90 \%$ of the diseases have a major genetic component or involve genetic factors that influence the disease in a significant manner ${ }^{(3)}$. On the other hand, the opinion manifested by $92 \%$ indicated a relevant relationship between genetic ophthalmopathies and the prevention of blindness through detection, early treatment and genetic counseling, while only $8 \%$ thought it was irrelevant.

This study revealed that the practical genetic knowledge acquired by a great majority of these interviewees was not enough since most of them $(84 \%)$ did not feel confident about giving information and counseling regarding the disease and its recurrence. Although $79 \%$ of the interviewees informed that they refer patients with genetic ophthalmopathies to specialized services that offer genetic counseling, 62\% stated that these referrals were rare. The frequency with which the genetic etiology of the patient's ophthalmopathy is suspected is questionable, as routine pedigrees and consanguineous investigations are performed by only a few ophthalmologists (10\% and $33 \%$, respectively, Table 3 ).

Genetic manipulation, pharmacogenetics and gene therapy will be fundamental subjects in this millennium and will have important ethical, political, social and economic implications Consequently, ophthalmologists as well as other physicians will have to be well informed in this area. The fact that $84 \%$ of the interviewees are aware of this factor is highly favorable (Table 4).

Considering that only $11 \%$ of the interviewees answered that these conditions are frequently found in their clinical practice, genetically determined conditions are still underestimated by the professionals. There is no doubt that the incorporation of a genetic perspective and the habit of thinking of those diseases not as rarities but as possibilities, will increase the rate of identification of these disorders.

\section{CONCLUSION}

All these promising scientific and technological advances in genetics will mean little if they do not benefit people. Genomic health care will be effective if the practice guidelines are based on research and its applications, as disease prevention, which is the common interest for both the discipline of epidemiology and community genetics. Considering this aspect, it is relevant to point out that a lot of programs involving community genetics have successfully been implanted in Brazil, regarding various genetic diseases, such as hemoglobinopathies, G-6-PD deficiency, mental retardation, congenital deafness, among others, which strongly demands the onset of visual deficiency programs, as well ${ }^{(26)}$. Therefore, it is important that in Brazil and in other developing countries genetic methodology should be vigorously discussed in a more pragmatic and less theoretical manner and also, further investigative research on this issue should be encouraged.

\section{RESUMO}

Objetivo: Verificar a percepção de oftalmologistas brasileiros em relação à contribuição da Genética em sua atuação médica rotineira, bem como a sua conduta em face de portadores de doenças hereditárias que necessitem de aconselhamento genético Métodos: Estudo transversal, em que duzentos oftalmologistas que atuam na região de Campinas, SP, Brasil (uni- 
versidades e/ou clínicas particulares) foram convidados a participar de uma entrevista sobre o assunto. Resultados: Aqueles que aceitaram o convite (36\%), enviaram um questionário respondido, via correio $(n=73)$. A importância das oftalmopatias genéticas em relação a sua freqüência na clínica prática foi relevante na opinião de $68 \%$ dos entrevistados e $92 \%$ manifestaram sua opinião como sendo muito importante a relação das oftalmopatias genéticas e a prevenção à cegueira, por meio da detecção e tratamento precoces e aconselhamento genético. Quanto à opinião dos entrevistados sobre melhorar seus conhecimentos em genética, $84 \%$ consideraram imprescindível, porém 16\% responderam que é irrelevante. Conclusões: De um modo geral, embora os oftalmologistas entrevistados tenham adquirido noções básicas de Genética (88\%) e estão conscientes de sua importância na prevenção da cegueira, os conhecimentos de genética da grande maioria dos oftalmologistas brasileiros são incompletos e, na prática, quase que inexplorados em seu potencial terapêutico e preventivo.

Descritores: Aconselhamento genético; Conhecimentos, atitudes e prática em saúde; Oftalmopatias hereditárias; Ceguei$\mathrm{ra} /$ prevenção \& controle

\section{REFERENCES}

1. Rosenberg T. Epidemiology of hereditary ocular disorders. Dev Ophthalmol. 2003;37:16-33.

2. François J. Genética e prevenção da cegueira. In: IV Congresso Brasileiro de Prevenção da Cegueira, Belo Horizonte, 1980. Proceedings. Belo Horizonte.

3. American Academy of Ophthalmology. Basic and clinical science course. Section 2. Fundamentals and principles of Ophthalmology. Los Angeles: Jules Stein Eye Institute; 1999-2000. p.183-302.

4. Gilbert C, Rahi J, Eckstein M, Foster A. Hereditary disease as a cause of childhood blindness: regional variation. Results of blind school studies undertaken in countries of Latin America, Asia and Africa. Ophthalmic Genet. 1995;16 (1): $1-10$.
5. Elder MJ, De Cock R. Childhood blindness in the West Bank and Gaza Strip: prevalence, aetiology and hereditary factors. Eye. 1993;7(Pt 4):580-3.

6. Gilbert C, Foster A. Childhood blindness in the context of VISION 2020-the right to sight. Bull World Health Organ. 2001;79(3):227-32.

7. Ten Kate LP. Editorial. Community Genet. 1998;1(1):1-2.

8. Ramalho AS, Silva RB. Community Genetics: a new discipline and its application in Brazil. Cad Saúde Pública. 2000;16(1):261-3.

9. Taylor HR. Fred Hollows lecture. Eye care for the community. Clin Experiment Ophthalmol. 2002;30(3):151-4.

10. Armond J, Temporini ER. [Ocular health beliefs among teachers in the public educational system of the city of Sao Paulo, SP, Brazil] Rev Saúde Pública. 2000;34(1):9-14. Portuguese.

11. Temporini ER, Kara N Jr, Jose NK, Holzchuh N. Popular beliefs regarding the treatment of senile cataract. Rev Saúde Pública. 2002;36(3):343-9.

12. Leavell HR, Clark EG. Medicina preventiva. São Paulo, Mcgraw-Hill; 1976.

13. Ramalho AS, Silva RB. Aconselhamento genético. In: Maciel-Guerra AT, Guerra Junior G, Editores. Menino ou menina? Os distúrbios da diferenciação do sexo. Barueri: Manole; 2002. p.208-17.

14. Ramalho AS. As hemoglobinopatias hereditárias: um problema de saúde pública no Brasil. Ribeirão Preto: Sociedade Brasileira de Genética; 1986.

15. Bartels DM, LeRoy BS, McCarthy P, Caplan AL. Nondirectiveness in genetic counseling: a survey of practitioners. Am J Med Genet. 1997;72(2):172-9.

16. Guttmacher AE, Jenkins J, Uhlmann WR. Genomic medicine: who will practice it? A call to open arms. Am J Med Genet. 2001;106(3):216-22.

17. Toledo R, Reis JC. Glaucoma congênito como causa de cegueira. An Oftalmol. 1983;2(1):102-5.

18. Greendale K, Pyeritz RE. Empowering primary care health professionals in medical genetics: how soon? How fast? How far? Am J Med Genet. 20011;106(3): 223-32. Comment in: Am J Med Genet. 20021 1;110(3):297; author reply 298-9.

19. Sallum, JMF. Aconselhamento genético. Arq Bras Oftalmol. 1996;59(3):327-9.

20. McDonald IM, Tran M, Musarella MA. Ocular genetics: current understanding. Surv Ophthalmol. 2004;49(2):159-96.

21. Baird PA. Toward an ideal human genetics curriculum in medical schools. Am J Hum Genet. 1989;44(1):166-7.

22. Robin NH. The good that we do. Am J Med Genet. 1996;65(4):257-8.

23. Harris R, Lane B, Harris H, Williamson P, Dodge J, Modell B, et al. National Confidential Enquiry into counselling for genetic disorders by non-geneticists: general recommendations and specific standards for improving care. Br J Obstet Gynaecol. 1999;106(7):658-63.

24. Walpole IR, Watson C, Moore D, Goldblatt J, Bower C. Evaluation of a project to enhance knowledge of hereditary diseases and management. J Med Genet. 1997;34(10):831-7.

25. Friedman JM. Association of Professors of Human or Medical Genetics: second annual workshop summary. Am J Med Genet. 1997;72(2):191-6.

26. Ramalho A. Genética Comunitária: uma alternativa oportuna e viável no Brasil. Bol Soc Bras Genet Clin. 2004;6(1):2-7.

\section{Research Days - UNIFESP}

\section{7 a 09 de Dezembro de 2006 São Paulo - SP}

Tel.: (11) 5085-2087 